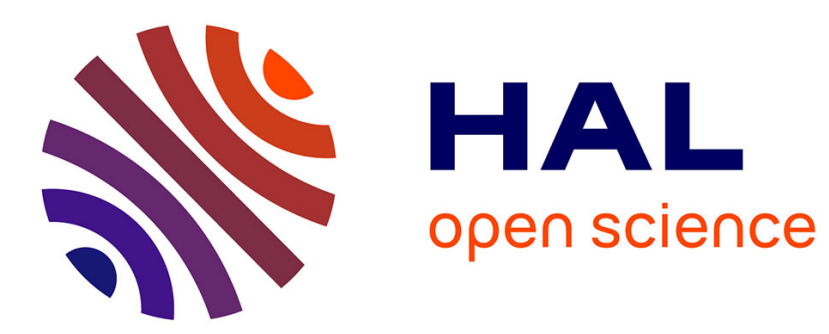

\title{
Inappropriate Choice of Definites in Turkish Heritage Speakers of German
}

\author{
Claudia Felser, Seçkin Arslan
}

\section{To cite this version:}

Claudia Felser, Seçkin Arslan. Inappropriate Choice of Definites in Turkish Heritage Speakers of German. Heritage Language Journal, 2019, 16(1). hal-02126829v2

\section{HAL Id: hal-02126829 \\ https://hal.science/hal-02126829v2}

Submitted on 11 Jun 2019

HAL is a multi-disciplinary open access archive for the deposit and dissemination of scientific research documents, whether they are published or not. The documents may come from teaching and research institutions in France or abroad, or from public or private research centers.
L'archive ouverte pluridisciplinaire HAL, est destinée au dépôt et à la diffusion de documents scientifiques de niveau recherche, publiés ou non, émanant des établissements d'enseignement et de recherche français ou étrangers, des laboratoires publics ou privés. 


\title{
Inappropriate Choice of Definites in Turkish Heritage Speakers of German
}

\author{
Claudia Felser \\ University of Potsdam \\ Seçkin Arslan \\ University of Côte d'Azur
}

\begin{abstract}
The appropriate use of (in-)definites can be notoriously difficult for language learners to acquire, suggesting that this linguistic domain is particularly prone to instability in language acquisition. The current study investigates whether heritage speakers also have difficulties in this domain. We report the results from a questionnaire study investigating heritage speakers' sensitivity to contextual cues to the appropriate use of (in-)definites both in their native language (Turkish) and in their second, societally dominant language (German). The results show that Turkish heritage speakers over-use definite noun phrases in contexts that normally require an indefinite noun phrase in both Turkish and German, in comparison to non-bilingual Turkish and German-speaking controls. This indicates that sensitivity to pragmatic constraints on the use of (in-)definites is reduced in languages that were acquired under conditions that differ from those of typical monolingually raised speakers, regardless of the age at which these languages were acquired or how definiteness is expressed morphosyntactically. Instead, our heritage speakers' daily use of Turkish proved to be the strongest predictor for their performance. Together, our findings indicate divergent attainment in both of our heritage speakers' languages, with pragmatic constraints on the use of (in-) definites being weakened in both Turkish and German.
\end{abstract}

KEYWORDS: Definiteness, bilingualism, heritage language, Turkish, German

\section{INTRODUCTION}

For languages in which noun phrases (NPs) are marked for definiteness, the contextually appropriate use of (in-)definites is a well-known source of difficulty in both native (L1) (e.g., Karmiloff-Smith, 1979; Maratsos, 1976; Schaeffer \& Matthewson, 2005) and second language (L2) acquisition (Hawkins et al., 2006; Huebner, 1983; Ionin, 2003; Master, 1987; Parodi, Schwartz, \& Clahsen, 2004; Thomas, 1989, to name but a few). Although the precise formal characterization of "definiteness" as a semantic category is controversial (Lyons, 1999), the use of a definite NPs is generally appropriate if both the speaker and the hearer can uniquely identify the NP's referent. This is usually referred to as the uniqueness (Hawkins, 1984) or familiarity (Heim, 1982) requirement. The uniqueness requirement holds that for the use of a definite description to be appropriate, there must be exactly one entity or set of entities in the world that satisfies that description. The familiarity requirement states that definite descriptions must be used to refer back to a discourse entity that has been explicitly or implicitly introduced by the current (discourse) context. Definiteness is often confounded with specificity, and the morphosyntactic forms indicating (in-)definiteness may also signal genericity or partitivity. The choice of definite versus indefinite forms thus depends on discourse-pragmatic cues that may be ambiguous and hard for language learners to evaluate, making the acquisition and target-like use of definiteness markers difficult.

Comparatively little is known about the possible erosion of definiteness distinctions in heritage language (HL) speakers who acquired a societally dominant second language alongside their 
home language during childhood or adolescence (Polinsky \& Kagan, 2007). Despite many differences, heritage speakers resemble L2 learners in that both an HL and an L2 are typically non-dominant languages that are acquired under reduced and variable input/output conditions. As Montrul (2012) points out, comparing HL and L2 speakers is useful for determining which aspects of linguistic knowledge are generally stable, and which show instability, in people who acquired a language under conditions that differ from those of typical monolingually raised speakers.

Phenomena whose mastery requires the integration of information from different linguistic domains have been claimed to be vulnerable or unstable both in L2 acquisition and under HL conditions (see Montrul, 2012, for a review). Keating, VanPatten and Jegerski (2011), for example, found that both HL speakers and L2 learners of Spanish differed from monolingually raised Spanish speakers in their interpretation preferences for null and overt pronouns. This finding is broadly consistent with the Interface Hypothesis (Sorace, 2011; compare also Montrul \& Polinsky, 2011), according to which even highly proficient bilinguals may show a reduced ability to integrate discourse-level and (morpho-)syntactic information. Note, however, that not all syntax-discourse phenomena necessarily show instability in HL speakers (Leal Méndez, Slabakova, \& Rothman, 2014, 2015).

Non-standard linguistic performance in an HL is often attributed to influence from the societally dominant language, even though speakers' performance in this language is rarely assessed independently for the phenomenon under investigation. The current study examines whether the ability to use contextual cues to definiteness marking is compromised in bilingual HL speakers and if so, whether this is language-selective or affects both of their languages. The two languages under investigation are Turkish and German, both of which mark definiteness morphosyntactically but in different ways.

\section{DEFINITENESS MARKING IN TURKISH AND GERMAN}

In Turkish, the definiteness status of object NPs is marked through the presence or absence of the prenominal indefinite determiner bir ("one") and through accusative case marking (e.g., Erguvanlı \& Zimmer, 1994; Özge, 2011; Von Heusinger \& Kornfilt, 2005); see Table 1 for an overview of definiteness distinctions. Definite nominal objects lack the indefinite determiner but must carry an accusative case suffix. As Turkish is a differential object marking language, the accusative case marker can also be omitted, which in the absence of bir gives rise to a kindlevel or generic reading (Göksel \& Kerslake, 2005). ${ }^{1}$ Turkish definites signal specific readings by default, whereas indefinites can be either specific or nonspecific (Enç, 1991). Nonspecific indefinites signal that an NP was not introduced in the preceding discourse, while specific indefinites refer to entities that were mentioned in the preceding discourse but are indefinite, such as partitives. 


\section{Table 1.}

Definiteness and Specificity Distinctions in Turkish Singular Object NPs.

\begin{tabular}{ll}
\hline Form & Example \\
\hline Definite & $\begin{array}{l}\text { kitabl } \\
\text { book.ACC } \\
\text { 'the book' }\end{array}$ \\
Indefinite non-specific & $\begin{array}{l}\text { bir kitap } \\
\text { 'a book' } \\
\text { Indefinite specific }\end{array}$ \\
& $\begin{array}{l}\text { bir kitabl } \\
\text { a book.ACC } \\
\text { 'one of the books' }\end{array}$ \\
\hline
\end{tabular}

In German, definiteness is signalled by prenominal articles that also inflect for gender, number and case; see Table 2 for an illustration. Unlike Turkish, German lacks morphosyntactically distinct indefinite specific forms.

Table 2.

Definiteness Distinctions in German (for Nominative and Accusative Singular Forms)

\begin{tabular}{lllc}
\hline Masculine & $\begin{array}{l}\text { Definite } \\
\text { Accusative }\end{array}$ & $\begin{array}{l}\text { der Hund } \\
\text { den Hund } \\
\text { "the dog" }\end{array}$ & $\begin{array}{c}\text { ein Hund } \\
\text { einen Hund } \\
\text { "a dog" }\end{array}$ \\
\hline Feminine & Nominative & die Katze & eine Katze \\
& Accusative Katze & eine Katze \\
& "the cat" & "a cat" \\
\hline Neuter & Nominative & das Buch & ein Buch \\
& Accusative & ein Buch \\
& "the book" & "a book" \\
\hline
\end{tabular}

In German, again unlike in Turkish, definiteness also plays a role in determining morphosyntactic concord within noun phrases. While prenominal adjectives in definite NPs must carry so-called "weak" inflection (1a), adjectives in indefinite NPs carry "strong" inflection (1b) (e.g., Bierwisch, 1967).
a. das neue Buch
"the new book"
b. ein neues Buch
"a new book"

Turkish-speaking learners of German thus need to learn (i) that (in-) definiteness in German is expressed through prenominal determiners whose semantics does not interact with case marking (which is obligatorily present in German), and (ii) how definiteness is involved in determining morphosyntactic concord within noun phrases. We will disregard other crosslinguistic differences concerning the expression of definiteness and the pragmatic functions of 
(in-)definite forms in Turkish and German (see, e.g., von Heusinger, 2002) here as these are not of interest to the current study.

\section{Acquiring Definiteness}

The target-like use of definite and indefinite forms emerges comparatively late in both Turkish and German L1 acquisition. German-speaking children acquire definiteness distinctions by about age three (Bittner, 1998), and although Turkish-speaking children acquire the accusative marker quite early (Ketrez \& Aksu-Koç, 2009) — and in the absence of the pronominal determiner bir the accusative marker may also signal definiteness - they do not reliably mark indefiniteness until about age 7 (Ketrez, 2015; Küntay, 2002). Turkish-German bilingual children have been found to show relatively high rates of article omission in German (Schönenberger, 2011).

Children acquiring article languages such as English have been reported to overuse definite forms in contexts that normally require an indefinite one. In the L1 acquisition literature, children's errors have been attributed to a lack of either pragmatic or semantic knowledge. Pragmatic accounts claim that children use definites to refer to salient referents (e.g. Maratsos, 1976) or to objects in their current focus of attention (Karmiloff-Smith, 1979) without taking into account the listener's knowledge. An alternative semantic account holds that for child L1 learners of English, the definite article the signals a partitive reading (Wexler, 2011).

Acquiring the correct use and interpretation of definite versus indefinite articles is also often problematic for post-childhood L2 learners, especially for native speakers of article-less languages (Hawkins et al., 2006; Huebner, 1983; Ionin, 2003; Ionin, Ko, \& Wexler, 2004; Ko, Ionin, \& Wexler, 2006, 2010; Master, 1987; Sleeman, 2004; Snape, 2006; Thomas, 1989; Trenkic, 2007, among others). Similar to child L1 learners, adult L2 learners of English often over-use definite articles in contexts that would normally require an indefinite, as in (2) below (example from Yang \& Ionin, 2009, p. 327).

(2) I have three pens in my bag. I will give you a pen / \#the pen.

Based on findings from a series of studies on the L2 acquisition of article semantics, Ionin et al. (2004) and Ko et al. (2006, 2010) suggested that L2 learners may take definite articles to signal specificity or a presupposition of existence rather than definiteness.

Regarding HL speakers, it is conceivable that they might not have acquired target-like sensitivity to definiteness distinctions in their home language due to HL-specific acquisition conditions (e.g. Kupisch \& Rothman, 2016; Montrul, 2008; Pascual y Cabo \& Rothman, 2012; Polinsky, 2006), or that sensitivity to definiteness distinctions in the HL has eroded following prolonged exposure to and frequent use of the societally dominant language (e.g., Schmid, 2011). Fenyvesi (2005), for example, reports an erosion of definiteness marking on verbs among Hungarian heritage speakers in the United States, with HL speakers using both the definite and the indefinite conjugation inappropriately. Montrul and Ionin (2010) found that both Spanish heritage speakers and L2 learners of Spanish in the United States interpreted plural definites as specific rather than as generic, while Spanish native speakers preferred a generic interpretation. This is suggestive of influence from the dominant language as plural definites tend to have a specific reading in English. Aalberse and Moro (2014) report an overuse of the nominal Malay definiteness marker -nya among heritage speakers of Malay living in the Netherlands. The authors attribute this tendency to influence from Dutch, in which where the use of definite articles is obligatory. While some studies have observed an overuse of definite 
forms among HL speakers, Backus, Doğruöz and Heine (2011) report that Turkish HL speakers living in the Netherlands over-extend the indefinite marker bir to contexts in which nonheritage native Turkish speakers would not use it.

Kupisch, Belikova, Özçelik, Stangen and White (2017), however, using acceptability judgement tasks, showed that Turkish-German bilinguals were as sensitive as non-bilingual native speakers to language-specific restrictions on the use of definites in existential sentences in both languages. Bilinguals correctly rejected German sentences such as (3) below (adapted from Kupisch et al., 2017, p. 14) which contain a definite NP in a strong negative context, while accepting equivalent sentences in Turkish, where this particular constraint against the use of definites does not apply.

$$
\begin{aligned}
& \text { *Es ist das Buch noch nicht hier. } \\
& \text { it is the book yet not here }
\end{aligned}
$$

'There's the book not here yet.'

The age at which German was acquired did not significantly affect the bilingual speakers' performance.

Together, previous findings could be taken to suggest that it is the pragmatically appropriate use of (in-)definites, not their grammatically appropriate use, that is vulnerable to erosion in HL speakers. However, previous studies differ considerably in their research methodologies, the kind of heritage speakers they chose for their study subjects, and the languages they spoke. Moreover, although HL speakers' reduced sensitivity in definiteness marking is often attributed to the influence of the dominant society language, HL speakers' performance in their second or dominant languages is rarely examined. Therefore, there is a need for a more systematic investigation of HL speakers' performance in both of their languages regarding the pragmatically appropriate use of (in-)definites. Here we follow Kupisch et al. (2017) in examining HL speakers in both of their languages to investigate their sensitivity to the contextually appropriate use of definites and indefinites in their L1 (Turkish) and L2 (German).

\section{The Current Study}

We carried out two offline discourse-completion experiments investigating Turkish-German bilingual speakers' sensitivity to definiteness distinctions in both of their languages. Our study addresses the following research questions:

1. To what extent do Turkish heritage speakers in Germany retain their sensitivity to definiteness distinctions in Turkish, as compared to non-bilingual Turkish native speakers and late bilingual Turkish-German speakers residing in Turkey?

2. To what extent do Turkish heritage speakers show sensitivity to definiteness distinctions in German, the societally dominant language, in comparison to native German-speaking controls?

The first question is examined in Experiment 1 and the second one in Experiment 2. In light of previous findings suggesting that the pragmatically appropriate use of (in-)definiteness is potentially problematic in both HL and L 2 speakers, we might expect heritage speakers to make 
more inappropriate choices in both of their languages compared to monolingually raised controls. These choices would suggest that the contextually appropriate use of (in-)definite forms is a locus of instability in people who acquired a given language under "divergent" conditions regardless of the age of acquisition. Alternatively, sensitivity to definiteness may be compromised selectively in either the heritage speakers' L1 (Turkish) or their L2 (German). An asymmetrical outcome would indicate the importance of individual factors such as age of acquisition or length and amount of exposure on bilinguals' ability to select contextually appropriate forms in a given language. $\stackrel{2}{2}$

\section{Experiment 1: Pragmatically ApPropriate Choice of (IN-)Definites in Turkish}

To examine participants' ability to select appropriate definite or indefinite forms in different kinds of discourse contexts, we used an untimed multiple-choice discourse-completion task (see, e.g., Liu, 2006). Discourse completion tasks are less metalinguistic in nature than acceptability judgments, and using a multiple-choice design keeps participants from providing continuations that are uninformative with respect to our research question. Although our main interest was to gauge whether the ability to select pragmatically appropriate continuations was compromised in speakers who had acquired Turkish under HL conditions, we also included a group of late Turkish-German bilinguals residing in Turkey as a further reference group, to assess whether knowledge of German - rather than HL conditions in general - might affect Turkish speakers' sensitivity to the phenomenon under investigation.

\section{Method}

Participants. Three groups of Turkish native speakers participated in the experiment. The participants included a group of Turkish speakers without knowledge of German $(n=25)$, a group of early bilingual speakers of Turkish and German (i.e., heritage speakers of Turkish living in the Berlin area of Germany, $n=20$ ), and a group of late bilingual speakers of Turkish and German (i.e., native Turkish speakers who started learning German at the age of 14 to 19, $\mathrm{n}=21$ ). The bilingual speakers were asked to self-rate their German and Turkish proficiencies on a 10-point scale for each of four language skills (speaking, listening, reading and writing); see Table 3 for a composite score. Self-ratings have been shown to correspond closely to proficiency scores obtained in formal language tests (e.g., Marian, Blumenfeld, \& Kaushanskaya, 2007), and here they also helped to ensure the comparability of scores across participants' languages.

The monolingual Turkish speakers and late bilinguals were living in Turkey at the time of testing and reported no extended stay abroad. The late bilingual group included Turkish students studying German as a foreign language at the Turkish-German University in Istanbul. They had all started to learn German after puberty, around the time they began their high school education (which in Turkey normally starts at age 14). The HL speakers included individuals with comparatively earlier contact to German. They reported speaking Turkish as their home or family language while their interaction with society was mostly in German. Three of our HL speakers were born in Turkey and subsequently immigrated to Germany; the others were born in Germany. Table 3 provides an overview of our participants' demographic details. 


\section{Table 3.}

Demographic Details of the Participants in Experiment 1 (LoS = length of stay in Germany, AoA = age of acquisition, language proficiency is based on participants' self-ratings; ranges are in parentheses).

\begin{tabular}{|c|c|c|c|c|c|c|c|c|c|}
\hline \multirow[t]{2}{*}{$\begin{array}{c}\text { Partici- } \\
\text { pants }\end{array}$} & \multirow[t]{2}{*}{$\mathbf{N}$} & \multirow[t]{2}{*}{ Age } & \multirow[t]{2}{*}{$\begin{array}{c}\text { LoS } \\
\text { (Months) }\end{array}$} & \multicolumn{2}{|c|}{$\begin{array}{c}\text { AoA } \\
(\text { Min/Max) }\end{array}$} & \multicolumn{2}{|c|}{$\begin{array}{c}\text { Language } \\
\text { Proficiency }(0 / 10)\end{array}$} & \multicolumn{2}{|c|}{$\begin{array}{c}\text { Daily Language } \\
\text { Use }(\%)\end{array}$} \\
\hline & & & & Turkish & German & Turkish & German & Turkish & German \\
\hline $\begin{array}{l}\text { Turkish } \\
\text { Mono- } \\
\text { linguals }\end{array}$ & 25 & $\begin{array}{c}23.80 \\
(21- \\
26)\end{array}$ & $\mathrm{NA}$ & $0 / 1$ & NA & $\begin{array}{c}9.47 \\
(7.75- \\
10)\end{array}$ & NA & 100 & 0 \\
\hline $\begin{array}{c}\text { Late } \\
\text { Bilinguals }\end{array}$ & 21 & $\begin{array}{c}19.28 \\
(18- \\
32) \\
\end{array}$ & $\mathrm{NA}$ & $0 / 1$ & $14 / 19$ & $\begin{array}{c}9.30 \\
(7.25- \\
10) \\
\end{array}$ & $\begin{array}{c}5.52 \\
(4.5-9)\end{array}$ & $\begin{array}{c}77.40 \\
(50- \\
100) \\
\end{array}$ & $\begin{array}{c}22.60 \\
(0-100)\end{array}$ \\
\hline $\begin{array}{l}\text { Heritage } \\
\text { Speakers }\end{array}$ & 20 & $\begin{array}{c}29.20 \\
(17- \\
45)\end{array}$ & $\begin{array}{c}293.68 \\
(120- \\
564)\end{array}$ & $0 / 1$ & $0 / 14$ & $\begin{array}{c}8.31 \\
(3.5-10)\end{array}$ & $\begin{array}{c}8.57 \\
(3-10)\end{array}$ & $\begin{array}{c}39.50 \\
(25- \\
100)\end{array}$ & $\begin{array}{c}60.50 \\
(50- \\
100)\end{array}$ \\
\hline
\end{tabular}

\section{Table 4.}

Example Context Stimuli and Expected Continuation Choices per Condition, Experiment 1

\begin{tabular}{|c|c|c|c|}
\hline Condition & Context Sentence 1 & Context Sentence 2 & Expected Answer Option \\
\hline Definite & $\begin{array}{l}\text { Masada bir kitap } \\
\text { vardl. }\end{array}$ & 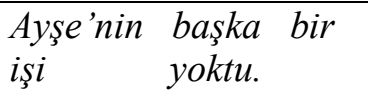 & $\begin{array}{l}\text { Ayşe kitabr } \\
\text { okudu. }\end{array}$ \\
\hline \multirow[t]{2}{*}{ Specific } & $\begin{array}{l}\text { table.LOC }_{\text {LOC }} \text { book.NOM } \\
\text { exist.PST }\end{array}$ & $\begin{array}{l}\text { Ayşe.GEN other one } \\
\text { duty.poss not.PST }\end{array}$ & $\begin{array}{l}\text { Ayşe book.ACC } \\
\text { read.pst }\end{array}$ \\
\hline & $\begin{array}{l}\text { 'There was a book on } \\
\text { the table.' }\end{array}$ & $\begin{array}{l}\text { 'Ayşe had nothing else } \\
\text { to do.' }\end{array}$ & 'Ayşe read the book.' \\
\hline Indefinite & Masada birkaç & Ayşe makale okumak & Ayşe bir \\
\hline \multirow[t]{3}{*}{ Nonspecific } & makale vardi. & istemiyordu. & okudu. \\
\hline & $\begin{array}{l}\text { table.LOC few article } \text { exist.pst }\end{array}$ & $\begin{array}{l}\text { Ayşe article read.INF } \\
\text { want.NEG.PROG.PST }\end{array}$ & $\begin{array}{l}\text { Ayşe one book } \\
\text { read.PST }\end{array}$ \\
\hline & $\begin{array}{l}\text { 'There were a few } \\
\text { articles on the table.' }\end{array}$ & $\begin{array}{l}\text { 'Ayşe did not want to } \\
\text { read articles.' }\end{array}$ & 'Ayşe read a book.' \\
\hline Indefinite & Masada kitaplar & Ayşe'nin başka bir & Ayşe bir \\
\hline \multirow[t]{3}{*}{ Specific } & vardl. & yoktu. & okudu. \\
\hline & $\begin{array}{l}\text { table.LOC }_{\text {book.PL }} \\
\text { exist.PST }\end{array}$ & $\begin{array}{l}\text { Ayşe.GEN other one } \\
\text { duty.Poss not.PST }\end{array}$ & $\begin{array}{l}\text { Ayşe one } \\
\text { book.ACC }_{\text {.ACad.PST }}\end{array}$ \\
\hline & $\begin{array}{l}\text { 'There were books on } \\
\text { the table.' }\end{array}$ & $\begin{array}{l}\text { 'Ayşe had nothing else } \\
\text { to do.' }\end{array}$ & $\begin{array}{l}\text { 'Ayşe read one of the } \\
\text { books.' }\end{array}$ \\
\hline
\end{tabular}


Materials. A total number of 24 inanimate NPs were chosen to create 24 two-sentence context stimuli in three conditions. Each stimulus context comprised a short initial sentence introducing some object or objects, which might be mentioned again in the continuation options, and a second sentence introducing a person referent and a brief statement about them. The context was manipulated to be pragmatically congruent with continuation sentences containing either a definite specific, an indefinite nonspecific or an indefinite specific NP, as illustrated in Table 4. All our continuation sentences were grammatical; they merely differed in whether they provided a pragmatically appropriate continuation of the preceding context.

In the Definite Specific (DS) condition, the context sentence contained an indefinite NP (e.g., bir kitap "a book"), making it appropriate to use the definite form at its second mention in the target sentence. In the Indefinite Nonspecific (IN) condition, the context sentence mentioned a set of objects (e.g., birkaç makale "a few articles") that differed from those mentioned in the answer options (e.g., kitap "book"). The NP in the target sentence thus lacks a corresponding antecedent NP. An NP that is mentioned for the first time should normally appear in its nonspecific indefinite form. In the Indefinite Specific (IS) condition, the context sentence included a plural NP (e.g., kitaplar "books") whose singular form also appeared in the target sentences. The prior mention of this plural NP should make it appropriate to use this NP in its indefinite specific form (e.g., bir kitabl "one of the books"), resulting in a partitive reading, although the corresponding nonspecific option (e.g., bir kitap "a book") would also fit the context as bir kitap would simply be understood here as referring to "any" book, possibly but not necessarily one from the set of books previously mentioned.

Procedures. The stimuli were programmed and presented via a web browser using Google Forms. Each participant was tested individually. The heritage speakers were tested under supervision by a research assistant in a dedicated laboratory room in Berlin. The non-bilingual Turkish-speaking controls were tested under supervision in various places in Turkey with assistance from our Turkey-based research collaborators, and the late bilinguals were tested remotely via the internet. Prior to the experimental task, participants were asked to fill in a demographic background and language history questionnaire. $\underline{3}$

The stimuli were distributed across three presentation lists, each of which contained an equal number of items from our three conditions, to ensure that a participant saw an experimental stimulus in one condition only. Each presentation list included 24 experimental items intermixed with 24 fillers, so that each list contained eight critical tokens from each context condition. The filler items also contained two-sentence contexts to be completed with an appropriate third sentence (e.g. Yerde kağıt parçaları var. Ben, onun kă̆ıdı yırttı̆̆ını gördüm. "There are pieces of paper on the floor. I saw that he was tearing the paper.") Continuation options included sentences with subject NPs that were either compatible or incompatible with an antecedent NP, or verb forms that were either compatible or incompatible with a temporal adverb used in one of the context sentences. Only one of the continuation options provided was appropriate.

Each stimulus item was presented on a separate page, with the context sentences shown in the middle of the screen, and followed by a blank line of underscores indicating that the text should be continued. Three answer options, that is, short sentences containing either a definite specific, indefinite nonspecific, or indefinite specific NP (as exemplified in Table 4) were provided beneath each context stimulus, with their order randomly shuffled for each item. Participants were asked to choose the sentence which in their opinion provided the most appropriate continuation of the preceding piece of discourse, by clicking to check the corresponding box in 
the electronic form. The experiment was programmed so as to allow for a single answer only, and so that participants could only move on to the next question once one of the boxes had been checked. Participants were instructed to proceed to the next item by clicking on the 'next' button at the bottom of the screen. The experiment took around 20 to 30 minutes to complete on average.

As the current study focuses on sensitivity to definiteness rather than specificity, statistical analyses were carried out for proportions of appropriate responses per condition. The continuation option that included a definite NP was the appropriate choice in the DS condition but an inappropriate one in both the IN and IS conditions. In the two indefinite conditions, continuation options with either a specific or nonspecific indefinite NP were both counted as appropriate. The data were analysed with mixed-effects logistic regression models in $\mathrm{R}$ using the lme4 package (Bates, Mächler, Bolker, \& Walker, 2015) to allow the inclusion of participants and experimental items as random factors. Post-hoc tests were performed using Tukey tests in R.

Results. Table 5 provides an overview of participants' answer choices per condition. In the DS condition, all three participant groups strongly favoured continuation sentences with a definite NP over those with an indefinite one. In both the IN and IS conditions, sentences with an indefinite nonspecific NP proved to be the most frequent choice across participant groups. However, our three participant groups patterned somewhat differently across experimental conditions. The HL speakers provided more than $20 \%$ inappropriate responses on average in each of the three experimental conditions, however, while the overall number of inappropriate choices made by the late bilinguals' and non-bilingual controls was lower. Both groups of bilinguals provided more inappropriate "indefinite" responses in the DS condition than the monolinguals did. In the two indefinite conditions, the HL speakers chose inappropriate "definite" continuations noticeably more often than did both of our non-heritage control groups.

\section{Table 5.}

Participants' Mean Percentages of Response Choices per Group and Condition in Experiment 1 .

\begin{tabular}{|l|c|c|c|c|c|c|c|c|c|}
\hline & \multicolumn{3}{|c|}{ MONOLINGUALS } & \multicolumn{2}{c|}{ HERITAGE SPEAKERS } & \multicolumn{3}{c|}{ L2 GERMAN SPEAKERS } \\
\hline $\begin{array}{c}\text { Condition/ } \\
\text { answer } \\
\text { option }\end{array}$ & $\begin{array}{c}\text { Definite } \\
\text { Specific }\end{array}$ & $\begin{array}{c}\text { Indefinite } \\
\text { Non- } \\
\text { specific }\end{array}$ & $\begin{array}{c}\text { Indefinite } \\
\text { Specific }\end{array}$ & $\begin{array}{c}\text { Definite } \\
\text { Specific }\end{array}$ & $\begin{array}{c}\text { Indefinite } \\
\text { Non- } \\
\text { specific }\end{array}$ & $\begin{array}{c}\text { Indefinite } \\
\text { Specific }\end{array}$ & $\begin{array}{c}\text { Definite } \\
\text { Specific }\end{array}$ & $\begin{array}{c}\text { Indefinite } \\
\text { Non- } \\
\text { specific }\end{array}$ & $\begin{array}{c}\text { Indefinite } \\
\text { Specific }\end{array}$ \\
\hline $\begin{array}{l}\text { kitabl } \\
\text { book.ACc } \\
\text { 'the book' }\end{array}$ & $\begin{array}{c}90 \% \\
(4-8)\end{array}$ & $\begin{array}{c}11.5 \% \\
(1-5)\end{array}$ & $\begin{array}{c}12 \% \\
(1-4)\end{array}$ & $\begin{array}{c}78.7 \% \\
(2-8)\end{array}$ & $\begin{array}{c}22.5 \% \\
(1-5)\end{array}$ & $\begin{array}{c}21.8 \% \\
(1-8)\end{array}$ & $\begin{array}{c}81.5 \% \\
(2-8)\end{array}$ & $\begin{array}{c}14.8 \% \\
(1-2)\end{array}$ & $\begin{array}{c}8.3 \% \\
(1-3)\end{array}$ \\
\hline $\begin{array}{l}\text { bir kitap } \\
\text { 'a book' }\end{array}$ & $\begin{array}{l}8.5 \% \\
(1-4)\end{array}$ & $\begin{array}{c}67 \% \\
(2-8)\end{array}$ & $\begin{array}{c}68.5 \% \\
(3-8)\end{array}$ & $\begin{array}{c}15.6 \% \\
(1-4)\end{array}$ & $\begin{array}{c}56.2 \% \\
(2-7)\end{array}$ & $\begin{array}{c}57.5 \% \\
(1-8)\end{array}$ & $\begin{array}{c}12.5 \% \\
(1-6)\end{array}$ & $\begin{array}{c}73.8 \% \\
(4-8)\end{array}$ & $\begin{array}{c}72.7 \% \\
(3-8)\end{array}$ \\
\hline $\begin{array}{l}\text { bir kitabl a } \\
\text { book.ACc } \\
\text { 'one of the } \\
\text { books' }\end{array}$ & $1.5 \%$ & $\begin{array}{c}21.5 \% \\
(1-2)\end{array}$ & $\begin{array}{c}19.5 \% \\
(1-4)\end{array}$ & $\begin{array}{c}5.6 \% \\
(1-3)\end{array}$ & $\begin{array}{c}21.3 \% \\
(1-4)\end{array}$ & $\begin{array}{c}20.6 \% \\
(1-4)\end{array}$ & $\begin{array}{c}5.9 \% \\
(1-3)\end{array}$ & $\begin{array}{c}11.3 \% \\
(1-3)\end{array}$ & $19 \%$ \\
\hline
\end{tabular}

a. appropriate answers are shaded. b. Ranges are provided in parentheses (maximum number of expected responses per condition per answer option is 8 ). 
Table 6 summarises the outputs from a general mixed-effects regression model with Group and Condition as fixed factors and with items and participants as random factors. Group was a significant effect both for the heritage speakers and the late bilinguals, signalling that both groups performed differently from the monolingual speakers overall. In addition, there were significant interactions between Group (late bilinguals versus monolinguals) and Condition.

\section{Table 6.}

Outputs from the main generalized linear mixed-effects regression model run on the response data from Experiment $1(\beta=$ estimate size, $\mathrm{SE}=$ standard error $)$.

\begin{tabular}{lllcc}
\hline Fixed Effects ${ }^{\dagger}$ & $B$ & SE & Z & $p$ \\
\hline Intercept & 2.62656 & 0.34781 & 7.552 & $<0.001$ \\
Condition (Indefinite Nonspecific) & -0.0457 & 0.34215 & -0.134 & 0.89353 \\
Condition (Indefinite Specific) & -0.1872 & 0.33290 & -0.562 & 0.57390 \\
Group (Heritage) & -1.10805 & 0.40713 & -2.722 & $0.006^{* *}$ \\
Group (L2 Speaker) & -1.1524 & 0.48967 & -2.354 & $0.018^{*}$ \\
Condition (Indefinite Nonspecific) x & -0.0633 & 0.44552 & -0.142 & 0.88701 \\
Group (Heritage) & & & & \\
Condition (Indefinite Specific) x Group & 0.10805 & 0.43645 & 0.248 & 0.80447 \\
(Heritage) & & & & \\
Condition (Indefinite Nonspecific) x & 1.54060 & 0.66955 & 2.301 & $0.021^{*}$ \\
Group (L2_German) & & & & \\
Condition (Indefinite Specific) x Group & 1.82239 & 0.63573 & 2.867 & $0.004 * *$ \\
(L2_German) & & & & \\
\hline
\end{tabular}

$\bar{\dagger}$ Code in R: glmer(Accuracy2 $\sim$ Condition * Group + (1 + Group | Item) + (1 | id), data=accuracy.TR, family = binomial)

The observed Group by Condition interactions are largely modulated by the late bilingual speakers. In the DS condition, both the HL speakers $(\beta=-0.895, \mathrm{SE}=0.306, \mathrm{z}=-2.920, p=0.009)$ and the late bilinguals $(\beta=-0.786, \mathrm{SE}=0.328, \mathrm{z}=-2.395, p=0.043)$ provided fewer appropriate responses than our monolingual Turkish-speaking controls. Furthermore, the late bilinguals and the HL speakers did not differ in their responses to the DS condition $(\beta=0.1088, \mathrm{SE}=0.298$, $\mathrm{z}=0.365, p=0.929)$. In the IN condition, by contrast, the heritage speakers chose fewer appropriate responses than both the monolinguals $(\beta=-1.240, \mathrm{SE}=0.454, \mathrm{z}=-2.729, p=0.017)$ and the late bilinguals $(\beta=1.741, \mathrm{SE}=0.529, \mathrm{z}=3.292, p=0.003)$. There was no statistical difference between the late bilinguals' and the Turkish monolingual speakers' responses in this condition $(\beta=0.500, \mathrm{SE}=0.510, \mathrm{z}=0.981, p=0.587)$. Finally, in the IS condition, the HL speakers also made fewer appropriate choices compared to both the monolinguals $(\beta=-0.841, \mathrm{SE}=0.305$, $\mathrm{z}=-2.761, p=0.015)$ and the late bilinguals $(\beta=1.368, \mathrm{SE}=0.368, \mathrm{z}=3.521, p<0.001)$. The late bilinguals again patterned with the Turkish monolinguals in this condition $(\beta=0.526, \mathrm{SE}=0.396$, $\mathrm{z}=1.326, p=0.377)$. 
To examine the potential influence of individual bilingualism variables on our heritage and late bilingual speakers' responses, we computed a second model for the bilingual data only. We included age of acquisition of German, percent of daily Turkish use, and self-rated proficiency in Turkish as factors in our model. The model outputs indicate a strong main effect of daily Turkish use $(\beta=0.012, \mathrm{SE}=0.003, z=-3.806, p<0.001)$, suggesting that lower daily Turkish use led to higher proportions of inappropriate responses. We found no significant effects of age of acquisition of German $(p=0.92)$ or of self-rated Turkish proficiency $(p=0.08) .{ }^{4}$

\section{Discussion}

The results from Experiment 1 show that both heritage speakers and late bilinguals chose more "indefinite" responses compared to monolingual Turkish-speaking controls in contexts that normally require a definite NP. However, only the HL speakers also over-extended the use of definites to indefinite contexts. Additional analyses showed that the likelihood of bilingual participants' providing inappropriate responses was inversely related to their daily use of Turkish, with less use of Turkish leading to more inappropriate continuation choices.

The greater number of "indefinite" responses in the DS position from bilingual groups as opposed to the monolingual controls could potentially be due to influence from German, where article use is obligatory, unlike in Turkish. Recall that an overuse of the Turkish indefinite marker bir was also observed by Backus et al. (2011) in Turkish HL speakers living in the Netherlands. A reviewer points out that the bilingual speakers' inappropriate use of indefinite continuations in the DS condition might also result from priming, given that the indefinite determiner bir appeared twice in the context sentences in this condition. Since an "indefinite" response was in fact appropriate in two of our experimental conditions, we also cannot rule out the possibility that at least some of the unexpected indefinite choices resulted from a probabilistic bias in our stimulus materials.

Most interestingly, our HL speakers differed from the late Turkish-German bilingual group regarding their overuse of definites. This finding can hardly be accounted for by negative transfer from the societally dominant language, because in pragmatic contexts corresponding to the IN and IS conditions in Experiment 1, an indefinite NP would also have been the most appropriate choice in German. Considering that two of the three possible discourse continuation options contained an indefinite NP, and two of our three context conditions actually favoured an indefinite response, participants' choice of an inappropriate definite response is also unlikely to reflect a probabilistic error or response strategy. Rather, it seems that sensitivity to the appropriate use of both indefinite and definite forms in Turkish is reduced in our HL speakers, as has previously been reported for HL speakers of other language combinations (e.g. Aalberse \& Moro, 2014; Backus et al., 2011; Fenyvesi, 2005).

There is no evidence in our data to suggest that Turkish HL speakers take definite forms to signal a presupposition of existence, as has previously been claimed for both children and L2 speakers of English (Ko et al., 2006, 2010; Wexler, 2011). Inappropriate "definite" continuations were chosen in around $22 \%$ of both the IN and IS trials, even though in the IN trials, the critical noun in the continuation sentence had not been mentioned in the preceding context. This makes it unlikely that our HL speakers interpreted definite NPs as referring to a member of a set introduced in the preceding discourse (Yang \& Ionin, 2009, p. 327).

In summary, the results from Experiment 1 support the idea that increased exposure to and use of a societally dominant language during childhood and adulthood, and a correspondingly reduced use of the L1 or family language, can lead to the erosion of grammatical distinctions 
in HL speakers. Our results are consistent with previous findings suggesting that phenomena that require the integration of morphosyntax and pragmatics are particularly vulnerable under HL conditions (e.g. Laleko \& Polinsky, 2013; Montrul, 2004). In Turkish HL speakers, a weakening of grammatical distinctions has also been observed for evidentiality marking, another pragmatically conditioned grammatical phenomenon (Arslan, Bastiaanse, \& Felser, 2015; Arslan, De Kok, \& Bastiaanse, 2017).

\section{EXPeriment 2: Pragmatically ApPropriate ChOiCe Of (IN-)definites In German}

Parallel to Experiment 1 on Turkish, our second experiment examined participants' sensitivity to pragmatic cues to the use of definite versus indefinite NPs in German. If HL speakers also overextend the use of definite NPs to indefinite contexts in their L2, we would expect them to provide more "definite" responses than our non-bilingual controls in the two indefinite conditions.

\section{Method}

Participants. Participants included the same $20 \mathrm{HL}$ speakers of Turkish who participated in Experiment 1, and a control group of native German speakers with no knowledge of Turkish $(\mathrm{N}=25$, mean age $=27.17$, range $=18-35)$. As the purpose of our study was to examine HL speakers in both of their languages and compare their performance to non-heritage native speakers', no additional group of late L2 learners of German was included.

Materials. Our critical experimental stimuli included 24 context sentences shown in three conditions, each of which was designed to elicit the use of either a definite or indefinite NP in the continuation options provided. The three experimental conditions are illustrated in Table 7.

\section{Table 7.}

Example Context Stimuli and Expected Continuation Choices per Condition, Experiment 2.

\begin{tabular}{|l|l|l|}
\hline $\begin{array}{l}\text { Condition } \\
\text { Definite }\end{array}$ & $\begin{array}{l}\text { Context Sentence } \\
\text { in.the office steht ein Telefon. } \\
\text { 'There is a telephone in the office.' }\end{array}$ & $\begin{array}{l}\text { Expected Answer Option } \\
\text { Das Telefon klingelt. } \\
\text { the telephone } \\
\text { rings }\end{array}$ \\
\hline $\begin{array}{l}\text { Indefinite } \\
\text { NP }\end{array}$ & $\begin{array}{l}\text { Im Büro stehen Telefone. } \\
\text { in.the office stand telephones is ringing.' } \\
\text { 'There are telephones in the office.' }\end{array}$ & $\begin{array}{l}\text { Ein Telefon klingelt. } \\
\text { a telephone rings }\end{array}$ \\
\hline $\begin{array}{l}\text { Indefinite } \\
\text { Quantifier }\end{array}$ & $\begin{array}{l}\begin{array}{l}\text { Im Büro stehen mehrere Telefone. } \\
\text { in.the office stand several } \\
\text { telephones }\end{array} \\
\begin{array}{l}\text { 'There are several telephones in the } \\
\text { office.' }\end{array}\end{array}$ & $\begin{array}{l}\text { Ein Telefon klingelt. } \\
\text { a telephone rings }\end{array}$ \\
\hline
\end{tabular}

The context sentences always introduced a singular or plural NP denoting some object or objects that were mentioned again in the continuation sentences, with half of the items manipulating definiteness of the subject NP and half manipulating definiteness of a direct object NP. As German lacks morphosyntactic specificity distinctions, only two possible continuation 
options (containing either a definite or an indefinite NP in the singular) were provided. In the Definite NP (DNP) condition, the context sentences introduced a singular indefinite NP (e.g. ein Telefon "a telephone"), which should trigger the use of a definite article when the corresponding object is referred to again in the continuation sentence. In our Indefinite NP (INP) condition, the context sentence signalled the presence of multiple objects by using a bare plural noun (e.g. Telefone "telephones"), and in the Indefinite Quantifier (IQ) condition plurality was additionally signalled by a plural quantifier such as mehrere "several." In both cases, the choice of an indefinite rather than a definite article is appropriate if one of the previously mentioned objects is referred to again in a subsequent sentence. Note that in both of our indefinite contexts, the indefinite article ein "one", which is homophonous with the numeral 'one', would normally be taken to signal partitivity (i.e. "one of the telephones"). The IQ condition was included so as to control for the possibility that our Turkish-speaking participants might overlook the plurality cue provided by bare plural nouns in the INP condition, a possibility for which we had some anecdotal evidence. The lexical-semantic plurality cue provided by a plural quantifier, on the other hand, was unlikely to be missed by our bilingual participants. If the bare plural nouns in our INP condition are mistaken for singular forms, then HL speakers should show more 'definite' responses in the INP than in the IQ condition.

To control for the possibility that non-targetlike responses from our HL speakers might simply reflect reduced sensitivity to the morphosyntactic encoding of definiteness in German, we constructed a further set of 12 stimulus items ("pseudo-fillers"). Exploiting the fact that morphosyntactic concord within German NPs is partly determined by the type of article used (definite versus indefinite), we created noun phrase contexts in which only a definite or an indefinite article was grammatically correct. Twelve pairs of grammatical and ungrammatical sentences, each preceded by a short introductory sentence that provided a general situational context, were created as illustrated in (4) and (5) below.

(4) Auf See zieht ein starker Wind auf.

at sea draws a strong wind up

'A strong wind is rising at sea.'

a. Das kleine Boot muss umkehren.

b. *Das kleines Boot muss umkehren. the small boat must turn.back

'The small boat needs to turn back.'

(5) Heute ist es sehr heiß. today is it very hot

'It is very hot today.'

a. Beate trinkt ein kaltes Wasser.

b. *Beate trinkt ein kalte Wasser. Beate drinks a cold water

'Beate is drinking a cold (glass of) water.' 
The ungrammatical continuation option would be grammatical if a different (definite or indefinite) article were used. That is, Option (4b) (in which the adjective carries 'strong' inflection) would be fine if das were replaced by ein, and option (5b) (where the adjective shows 'weak' inflection) would be fine if ein were replaced by das. Half of our items contained definite and half indefinite noun phrases, with the critical NP's grammatical function (subject versus object) counterbalanced.

Procedures. The experimental stimuli were distributed across three presentations lists, and the items in each list were mixed with our 12 pseudo-fillers plus 14 additional fillers, and then pseudo-randomized. The filler items offered continuation sentences whose inappropriate versions included agreement, gender or case violations. Half of the filler continuation sentences resembled the experimental sentences in that they included a noun phrase referring back to an antecedent noun phrase in the context sentence. The procedures were the same as in Experiment 1. The HL speakers completed both the German and Turkish experiments within the same session, with the order of language being counterbalanced across participants.

One experimental item was excluded from analysis due to a coding error. For the purpose of statistical analysis, "definite" answers were counted as appropriate in the DNP condition and as inappropriate otherwise, while only "indefinite" responses were considered appropriate in the INP an IQ conditions.

\section{RESULTS.}

Table 8 provides an overview of participants' responses to the three context conditions. Overall the heritage speakers provided fewer expected "definite" and an "indefinite" answer choices across the three experimental conditions than did the monolingual German speakers. Table 9 shows the outputs from our general mixed-effects regression model with Group and Condition as fixed factors. The outputs showed significant effects of Group, Condition, and a significant interaction between the two.

\section{Table 8.}

Participants' Mean Percentages of Response Choices per Group and Condition in Experiment 2, with Appropriate Answers Shaded.

\begin{tabular}{|l|c|c|c|c|c|c|}
\hline & \multicolumn{3}{|c|}{ MONOLINGUALS } & \multicolumn{3}{c|}{ HERITAGE SPEAKERS } \\
\hline $\begin{array}{c}\text { Condition / } \\
\text { answer option }\end{array}$ & Definite NP & $\begin{array}{c}\text { Indefinite } \\
\text { NP }\end{array}$ & $\begin{array}{c}\text { Indefinite } \\
\text { Quantifier }\end{array}$ & Definite NP & $\begin{array}{c}\text { Indefinite } \\
\text { NP }\end{array}$ & $\begin{array}{c}\text { Indefinite } \\
\text { Quantifier }\end{array}$ \\
\hline Definite NP & $94 \%$ & $10 \%$ & $9 \%$ & $83 \%$ & $35 \%$ & $30 \%$ \\
(das Telefon) & $(6-8)$ & $(1-1)$ & $(1-2)$ & $(2-8)$ & $(1-7)$ & $(1-6)$ \\
\hline Indefinite NP & $6 \%$ & $90 \%$ & $91 \%$ & $17 \%$ & $65 \%$ & $70 \%$ \\
(ein Telefon) & $(1-2)$ & $(7-7)$ & $(6-7)$ & $(1-6)$ & $(2-7)$ & $(1-7)$ \\
\hline
\end{tabular}

a. Ranges are provided in parentheses (maximum number of expected responses per condition per answer option is 8 ). 
Table 9.

Outputs from the Main Generalized Linear Mixed-Effects Regression Model Run on the Accuracy of Responses to Experiment $2(\beta=$ estimate size, $S E=$ standard error $)$.

\begin{tabular}{llccl}
\hline Fixed effects ${ }^{\dagger}$ & $\beta$ & $\mathrm{SE}$ & $\mathrm{z}$ & $p$ \\
\hline Intercept & 5.018 & 0.825 & 6.077 & $<0.001$ \\
Condition (Indefinite Plural) & -0.041 & 1.063 & -0.039 & 0.968 \\
Condition (Indefinite Quantifier) & -0.516 & 0.990 & -0.521 & 0.602 \\
Group & -1.876 & 0.571 & -3.281 & $0.001^{* *}$ \\
Condition (Indefinite Plural) x Group & -2.318 & 0.881 & -2.629 & $0.008^{* *}$ \\
Condition (Indefinite Quantifier) x Group & -1.159 & 0.757 & -1.531 & 0.125
\end{tabular}

${ }^{\dagger}$ Code in R: glmer(Accuracy $\sim$ Condition * Group + (1 |subject) + (1 | item), data=accuracy, family=binomial)

Since we found a significant interaction between Group and Condition, we further explored the data using post-hoc Tukey tests. Cross-groups comparisons indicate that the Turkish HL speakers provided fewer appropriate responses than the German monolingual controls in all three conditions (Definite NP: $\beta=1.943, \mathrm{SE}=0.5779, \mathrm{z}=3.363, p<0.001$; Indefinite NP: $\beta=5.574$, $\mathrm{SE}=1.149, \mathrm{z}=4.853, p<0.0001$; Indefinite Quantifier: $\beta=2.629, \mathrm{SE}=0.576, \mathrm{z}=4.56, \mathrm{p}<0.0001)$. Within-group comparisons from a set of post-hoc Tukey tests revealed that the heritage speakers provided a larger number of expected responses in the DNP than in both the INP $(B=$ -1.244, $\mathrm{SE}=0.281, \mathrm{z}=-4.426, \mathrm{p}<0.0001)$ and IQ conditions $(\beta=-1.022, \mathrm{SE}=0.282, \mathrm{z}=-3.615, \mathrm{p}=$ $0.0008)$. They did not differ in their responses to the INP and IQ conditions $(\beta=0.222$, $\mathrm{SE}=0.243, \mathrm{z}=0.914, p=0.63)$.

To examine the influence of bilingualism factors on the HL speakers' response patterns in Experiment 2, a subsequent model was built for the HL speakers' data. The variables explored were age of acquisition of German, percentage of daily use of Turkish, and self-rated proficiency in German. Our model outputs showed significant effects of daily use of Turkish $(\beta=-0.021, \quad \mathrm{SE}=0.009, \quad \mathrm{z}=-2.214, \quad p=0.026)$, implying that the more Turkish-and correspondingly less German - our HL speakers used in their daily lives, the greater the number of inappropriate responses they provided. However, we found no significant effects of age of acquisition of German $(p=0.15)$ or of self-rated German proficiency $(p=0.81)$.

On the pseudo-fillers examining sensitivity to morphosyntactic concord, the German monolinguals performed at ceiling. The HL speakers were $84 \%(\mathrm{SD}=32)$ accurate in responding to items that required definite NPs and $87 \%(\mathrm{SD}=31)$ accurate for items that required indefinite NPs in the target sentences. This difference did not prove statistically significant (Wilcoxon, $\mathrm{Z}=6960, \mathrm{p}=0.460)$.

Discussion. The results from Experiment 2 parallel those from Experiment 1 in showing that HL speakers also overuse definite forms in indefinite-biased contexts in German; see Figure 1 for a graphical comparison of the results from both experiments. Similar problems with the appropriate use of definite forms have frequently been attested in L2 speakers of article languages like English, in particular in speakers whose L1 lacks an article system (see Huebner, 1983; Master, 1987; Thomas, 1989, and many subsequent studies). Our HL speakers' 
proportions of inappropriate 'definite' responses did not significantly differ between the INP and IQ conditions, which suggests that the over-extension of definites to indefinite contexts is unlikely to be due to a lack of sensitivity to the antecedent noun's plural feature in the INP condition. As in Experiment 1, the amount of daily use of Turkish versus German influenced the likelihood of the HL speakers' providing inappropriate responses.

Our HL speakers also provided more inappropriate 'indefinite' responses in the DNP condition than did the German native speakers, but this happened to a much smaller degree compared to their inappropriate choices of "definite" responses. As in our Turkish experiment, inappropriate "indefinite" responses might at least partly reflect a probabilistic bias in our materials and thus should be interpreted with caution.

Figure 1. Overall Percentages of Monolingual and HL Speakers' Inappropriate 'Definite' Responses in Turkish (Experiment 1) and German (Experiment 2).

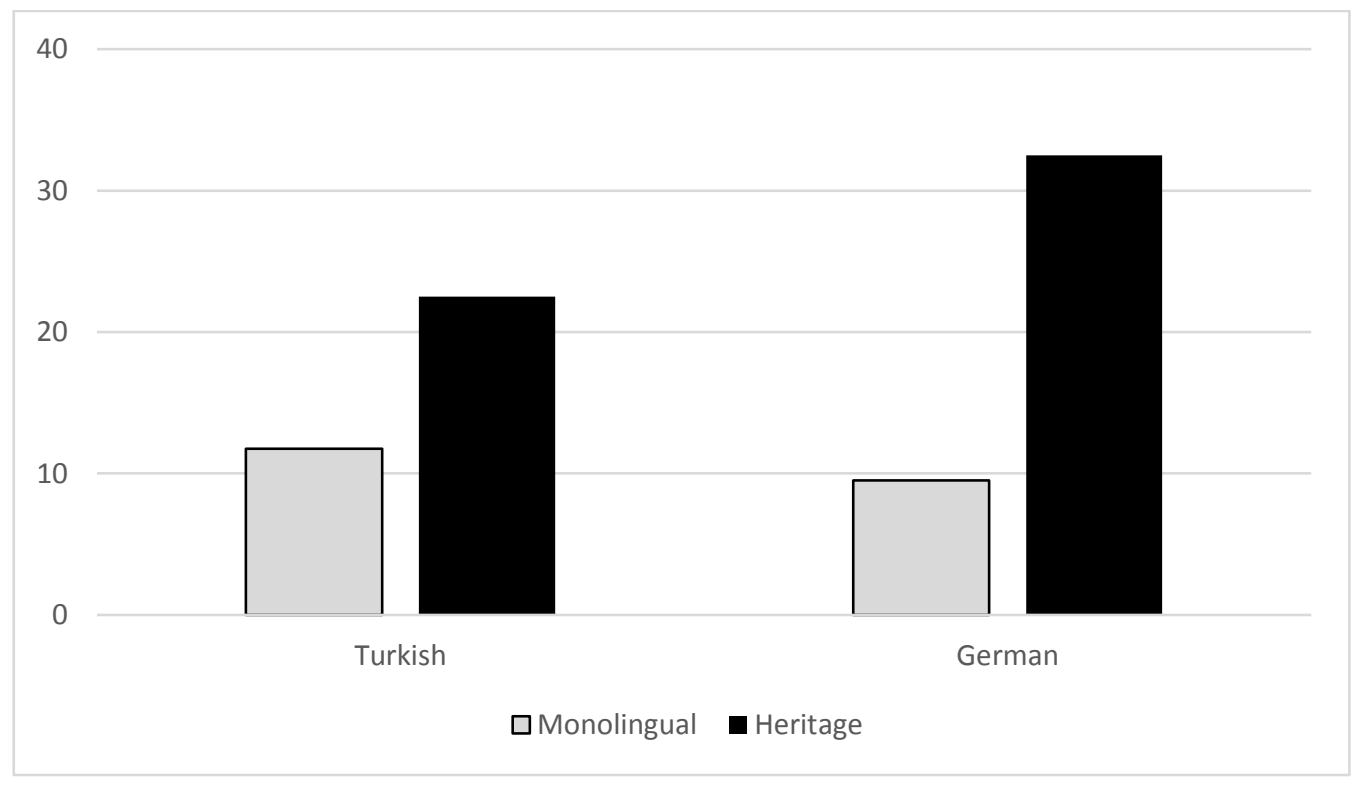

Although our HL speakers performed worse overall than the native German-speaking controls on our pseudo-fillers testing morphosyntactic concord, given that German nominal concord is notoriously difficult for language learners to master (Parodi et al., 2004), the HL speakers' answer accuracy was quite high. There was no evidence of a definite/indefinite asymmetry of the kind that was observed in their pragmatically conditioned continuation choices. Our HL speakers' non-target-like pragmatic use of definites in Experiment 2 thus seems unlikely to reflect a general lack of knowledge of the grammatical properties of German definite articles.

\section{GENERAL DiscuSSION}

In this study, we asked whether Turkish-German bilinguals would show reduced sensitivity to the contextually appropriate use of (in-)definite NPs in either or both of their languages, compared to non-bilingual controls. The results from Experiments 1 and 2 show that Turkish HL speakers over-extended the use of definites to pragmatic contexts that normally require an indefinite NP in both Turkish and German. Our results thus reveal striking similarities between the outcomes of HL and L2 acquisition in a linguistic domain that requires the integration of morphosyntactic and pragmatic knowledge, although German is an article language whereas Turkish lacks an article system. This shows that definiteness distinctions are indeed prone to instability in languages that were acquired under reduced input/output conditions, irrespective 
of how definiteness is expressed. Given that our HL speakers acquired both Turkish and German under conditions that differed from those obtaining in typical monolingual L1 acquisition, parallel outcomes for phenomena that are known to be difficult to acquire for both children and L2 learners are not surprising (Montrul, 2012).

As adult HL speakers can hardly be argued to lack the general pragmatic skills needed for establishing common ground or shared speaker-hearer knowledge (as might be argued for young children), their non-target-like use of definites in both their L1 and L2 seems more likely to reflect a degree of semantic or pragmatic bleaching. Definite forms may tend to be used as underspecified or default forms by Turkish HL speakers in cases of uncertainty, possibly due to the uniqueness or familiarity constraint on definites being weakened in HL speakers' grammars. Alternatively, it is possible that our HL speakers were sensitive to the uniqueness requirement but over-relied on discourse-level cues such as previous mention, as has been suggested by Yang and Ionin (2009) to account for English L2 learners' non-target-like acceptability judgements. Although previous mention could have influenced our HL speakers' continuation choices in German, this hypothesis cannot account for their response pattern in Turkish. In Experiment 1, our HL speakers chose inappropriate definite continuations to a similar extent in both the IN and IS conditions, although the critical noun (e.g. kitap "book") was not mentioned at all in the context preceding the target sentence in the IN condition. As we noted above, this observation also makes it unlikely that our HL speakers understood definites to signal a presupposition of existence (rather than presuppositions of both uniqueness and existence).

The cross-language similarity of our HL speakers' response patterns does not necessarily mean that the observed L1/L2 parallels can be attributed to the same source in both languages. One obvious potential source for HL speakers' divergent performance in a given linguistic domain is influence from the societally dominant language (e.g. Montrul \& Ionin, 2010, 2012). The over-extension of definite NPs in HL speakers' Turkish is unlikely to be due to backwards transfer from German, however. If anything, the rule that singular common nouns must be preceded by an article in German should have biased our HL speakers towards over-using the indefinite marker bir rather than definites, which are bare nouns in Turkish. We did indeed observe a larger proportion of inappropriate "indefinite" responses, in comparison to nonbilingual Turkish-speaking controls, in both of our L2 German-speaking participant groups (compare also Backus et al., 2011). Our HL speakers' over-use of definites is not consistent with such a tendency, however, and also goes against a probabilistic bias towards indefinite responses in our stimulus materials.

As regards our HL speakers' misuse of definites in German, the societally dominant language, it is conceivable that the hypothesized weakening of pragmatic constraints on the use of definites in their L1 was carried over to German. Alternatively, a failure to acquire monolingual-like sensitivity to the appropriate use of definites in German may have been an independent consequence of this phenomenon's inherent difficulty for learners of German as a second or additional language. Although the present findings do not allow us to distinguish between these two possibilities, our results suggest that definite NPs are semantically or pragmatically underspecified (and hence overused) in both of our HL speakers' languages.

\section{CONCLUSION}

Syntax-discourse phenomena often show instability in both HL speakers and L2 learners (Montrul, 2012). In the current study, we examined Turkish-German bilinguals in both of their languages to investigate whether potential problems with the appropriate use of definiteness 
markers are language-selective or affect both the L1 and L2. Our results show that TurkishGerman HL speakers overextend the use of definite NPs to pragmatic contexts that normally require an indefinite one in both Turkish and German. These patterns are largely predicted by the amount of Turkish our HL speakers use in their daily lives. A low amount of Turkish use led to more inappropriate responses in Turkish (Experiment 1) but to a larger number of appropriate responses in German (Experiment 2). The fact that definiteness is marked differently in Turkish and German - specifically, the lack of definite articles in Turkish - did not seem to affect our HL speakers' cross-linguistic performance. Our findings thus provide further evidence in support for the hypothesis that semantic or pragmatic constraints on the choice of grammatical forms are particularly prone to weakening in both HL and L2 grammars.

\section{ACKNOWLEDGEMENTS}

This research was supported by an Alexander-von-Humboldt professorship awarded to Harald Clahsen, and partly funded by the Deutsche Forschungsgemeinschaft (DFG, German Research Foundation), Collaborative Research Centre SFB 1287, Project B04. We thank Jane Kühn for help with the materials creation and data collection, Manolya Saglam Akyüz and Simge Sargin for their help with the data collection, and Aysel Uzuntaş for data collection assistance and helpful advice and discussion.

\section{REFERENCES}

Aalberse S., \& Moro F. R. (2014), Stability in Chinese and Malay heritage languages as a source of divergence. In K. Braunmüller, S. Höder, K. Kühl (Eds.), Stability and divergence in language contact: Factors and mechanisms (pp. 141-162). Amsterdam: John Benjamins.

Arslan, S., Bastiaanse, R., \& Felser, C. (2015). Looking at the evidence in visual world: eyemovements reveal how bilingual and monolingual Turkish speakers process grammatical evidentiality. Frontiers in Psychology 6:1387. doi:10.3389/fpsyg.2015.01387

Arslan, S., De Kok, D., \& Bastiaanse, R. (2017). Processing grammatical evidentiality and time reference in Turkish heritage and monolingual speakers. Bilingualism: Language and Cognition, 20(3), 457-472.

Backus, A., Doğruöz, A. S., \& Heine, B. (2011). Salient stages in contact-induced grammatical change: Evidence from synchronic vs. diachronic contact situations. Language Sciences, 33(5), 738-752.

Bates, D., Mächler, M., Bolker, B., \& Walker, S. (2015). Fitting Linear Mixed-Effects Models Using lme4. Journal of Statistical Software, 67(1), 1-48.

Bierwisch, M. (1967). Syntactic features in morphology: General problems of so-called pronominal inflection in German. In To Honor Roman Jakobson, Vol. 1 (pp. 239-270). The Hague: Mouton.

Bittner, D. (1998). Entfaltung grammatischer Relationen im NP-Erwerb: Referenz. Folia Linguistica XXXI, 255-283.

Enç, M. (1991). The semantics of specificity. Linguistic Inquiry, 22, 1-25.

Erguvanl1, E., \& Zimmer, K. (1994). Case marking in Turkish indefinite object constructions. Annual Meeting of the Berkeley Linguistics Society, 20(1), 547-552.

Fenyvesi, A. (2005). Hungarian in the United States. In A. Fenyvesi (Ed.), Hungarian language contact outside Hungary: Studies in Hungarian as a minority language (pp. 265-318). Amsterdam, The Netherlands: John Benjamins.

Göksel, A., \& Kerslake, C. (2005). Turkish: A comprehensive grammar. New York, NY: Routledge.

Hawkins, J. A. (1984). A note on referent identifiability and co-presence. Journal of Pragmatics, 8, 649-659. 
Hawkins, R., Al-Eid, S., Almahboob, I., Athanasopoulos, P., Chaengchenkit, R., Hu, J., ..., Velasco-Zárate, K. (2006). Accounting for English article interpretation by L2 speakers. EUROSLA Yearbook, 6, 7-25.

Heim, I. (1982). The semantics of definite and indefinite noun phrases (Unpublished doctoral dissertation). University of Massachusetts, Amherst.

Huebner, T. (1983). A longitudinal analysis of the acquisition of English. Ann Arbor, MI: Karoma.

Ionin, T. (2003). Article semantics in second language acquisition (Unpublished doctoral dissertation). Massachusetts Institute of Technology, Cambridge.

Ionin, T., Ko, H., \& Wexler, K. (2004). Article semantics in L2 acquisition: The role of specificity. Language Acquisition, 12(1), 3-69.

Karmiloff-Smith, A. (1979). A functional approach to child language. Cambridge, UK: Cambridge University Press.

Keating, G., VanPatten, B. \& Jegerski, J. (2011). Who was walking on the beach? Anaphora resolution in Spanish heritage speakers and adult second language learners. Studies in Second Language Acquisition, 33, 193-222.

Ketrez, F. N. (2015). Incomplete acquisition of the differential object marking in Turkish. Revue Roumaine de Linguistique LX (4), 421-430.

Ketrez, F. N., \& Aksu-Koç, A. (2009). Early nominal morphology: Emergence of case and number. In U. Stephany \& M. D. Voeikova (Eds.), Development of nominal inflection in first language acquisition: A cross-linguistic perspective (pp. 15-48). Berlin, Germany: Mouton de Gruyter.

Ko, H., Ionin, T., \& Wexler, K. (2006). Adult L2-learners lack the Maximality presupposition, too! In K. U. Deen, J. Nomura, B. Schulz, \& B. D. Schwartz (Eds.), Proceedings of the Inaugural Conference on Generative Approaches to Language Acquisition-North America, Honolulu, HI (pp. 171-182). Storrs, CT: University of Connecticut Occasional Papers in Linguistics, Vol. 4.

Ko, H., Ionin, T., \& Wexler, K. (2010). The role of presuppositionality in the second language acquisition of English articles. Linguistic Inquiry, 41, 213-254

Küntay, A. C. (2002). Development of the expression of indefiniteness: Presenting new referents in Turkish picture-series stories. Discourse Processes, 33(1), 77-101.

Kupisch, T., Belikova, A., Özçelik, Ö., Stangen, I., \& L. White (2017). On complete acquisition in heritage speakers: The definiteness effect in German-Turkish bilinguals. Linguistic Approaches to Bilingualism, 7(1), 1-32.

Kupisch, T., \& Rothman, J. (2016). Terminology matters! Why difference is not incompleteness and how early child bilinguals are heritage speakers. International Journal of Bilingualism, 22(5), 564-582. doi: 10.1177/1367006916654355.

Laleko, O., \& M. Polinsky. (2013). Marking topic or marking case? Heritage Language Journal, 10(2), 40-64. Available from http://www.heritagelanguages.org

Leal Méndez, T., Slabakova, R., \& Rothman, J. (2015). Discourse-sensitive clitic-doubled dislocations in heritage Spanish. Lingua, 155, 85-97.

Leal Méndez, T., Slabakova, R., \& Rothman, J. (2014). A rare structure at the syntax-discourse interface: Heritage and Spanish-dominant native speakers weigh in. Language Acquisition, 21(4), 411-429.

Liu, J. (2006). Measuring interlanguage pragmatic knowledge of EFL learners. Frankfurt, Germany: Peter Lang.

Lyons, C. (1999). Definiteness. Cambridge, UK: Cambridge University Press.

Maratsos, M. P. (1976). The use of definite and indefinite reference in young children. Cambridge, UK: Cambridge University Press. 
Marian, V., Blumenfeld, H. K., \& Kaushanskaya, M. (2007). The language experience and proficiency questionnaire (LEAP-Q): Assessing language profiles in bilinguals and multilinguals. Journal of Speech Language and Hearing Research, 50(4), 940-967.

Master, P. (1987). A cross-linguistic interlanguage analysis of the acquisition of the English article system (Unpublished doctoral dissertation). University of California, Los Angeles.

Montrul, S. (2004). Subject and object expression in Spanish heritage speakers: A case of morpho-syntactic convergence. Bilingualism: Language and Cognition, 7(2), 125-142.

Montrul, S. (2008). Incomplete acquisition in bilingualism. Re-examining the age factor. Amsterdam, The Netherlands: John Benjamins.

Montrul, S. (2012). Is the heritage language like a second language? EUROSLA Yearbook, 12, $1-29$.

Montrul, S., \& Ionin, T. (2010). Transfer effects in the interpretation of definite articles by Spanish heritage speakers. Bilingualism: Language and Cognition, 13(4), 449-473.

Montrul, S., \& Ionin, T. (2012). Dominant language transfer in Spanish heritage speakers and L2 learners in the interpretation of definite articles. The Modern Language Journal, 96(2), 70-94.

Montrul, S., \& Polinsky, M. (2011). Why not heritage speakers?. Linguistic Approaches to Bilingualism, 1, 58-62.

Özge, U. (2011). Turkish indefinites and accusative marking. In Aldridge, E. (Ed.), Proceedings of the 7th Workshop on Altaic Formal Linguistics (pp. 253-267). Cambridge, MA: MITWPL.

Parodi, T., Schwartz, B. D., Clahsen, H. (2004). On the L2 acquisition of the morphosyntax of German nominals. Linguistics, 42(3), 669-705.

Pascual y Cabo, D. and Rothman, J. (2012) The (il)logical problem of heritage speaker bilingualism and incomplete acquisition. Applied Linguistics, 33(4), 450-455.

Polinsky, M. (2006). Incomplete acquisition: American Russian. Journal of Slavic Linguistics, 14, 191-262.

Polinsky, M., \& Kagan, O. (2007). Heritage languages: In the 'wild' and in the classroom. Language and Linguistics Compass, 1(5), 368-395.

Potsdam Research Institute for Multilingualism (n.d.). Language background questionnaires. Available from https://www.uni-potsdam.de/en/prim/labs-experiments/taking-part-inexperiments.html

Schaeffer, J., \& Matthewson, L. (2005). Grammar and pragmatics in the acquisition of article systems. Natural Language \& Linguistic Theory, 23, 53-101.

Schmid, M. (2011). Language attrition. Cambridge, UK: Cambridge University Press.

Schönenberger, M. (2011). Are Difficulties with the Prosodic Representation the Origin of Prolonged Article Omission? In J. Herschensohn, \& D. Tanner (Eds.), Proceedings of the 11th Generative Approaches to Second Language Acquisition Conference (GASLA 2011) (pp. 135-142). Somerville, MA: Cascadilla Press.

Sleeman, P. (2004). The acquisition of definiteness distinctions by L2 learners of French. Linguistics in the Netherlands, 21(1), 158-168.

Snape, N. (2006). L2 acquisition of definiteness and specificity in English by advanced Japanese and Spanish learners. In A. Belletti, E. Bennati, C. Chesi, E. Di Domenico and I. Ferrari (Eds.), Language acquisition and development. Proceedings of the Generative Approaches to Language Acquisition Conference 2005 (pp. 591-596). Cambridge, UK: Cambridge Scholars Press.

Sorace, A. (2011). Pinning down the concept of "interface" in bilingualism. Linguistic Approaches to Bilingualism, 1, 1-33.

Taylan, E. E. (1984). The function of word order in Turkish grammar. Berkeley, CA: University of California Press. 
Thomas, M. (1989). The acquisition of English articles by first- and second-language learners. Applied Psycholinguistics, 10, 335-355.

Trenkic, D. (2007). Variability in L2 article production: Beyond the representational deficit vs. processing constraints debate. Second Language Research, 23, 289-327.

Wexler, K. (2011). Cues don't explain learning: Maximal trouble in the determiner system. In E. Gibson \& N. Pearlmutter (Eds.), The processing and acquisition of reference (pp.15-42). Cambridge, MA: MIT Press.

Von Heusinger, K. (2002). The cross-linguistic implementations of specificity. In K. Jaszczolt \& K. Turner (Eds.). Meaning through Language Contrast, Vol. 2 (pp. 405-421). Amsterdam, The Netherlands: John Benjamins.

Von Heusinger, K., \& Kornfilt, J. (2005). The case of the direct object in Turkish: Semantics, syntax and morphology. Turkic Languages, 9, 3-44.

Yang, M., \& Ionin, T. (2009). L2 English Articles and the Computation of Uniqueness. In J. Crawford, K. Otaki, \& M. Takahashi (Eds.), Proceedings of the 3rd Conference on Generative Approaches to Language Acquisition-North America, University of Connecticut (pp. 325-335). Somerville, MA: Cascadilla Press. 


\section{Notes}

1. Bare nouns without an accusative marker are usually considered to be incorporated objects, as in Ali her gün kitap okuyor "Ali does book-reading every day" (see Erguvanlı \& Zimmer, 1994, p. 547). We have not included this particular form in the current study because of its non-referential status, as proposed by Taylan (1984).

2. The research reported was approved by the ethics committee of the University of Potsdam (application number 37/2011).

3. Language background questionnaires used at our institute can be requested via the contact form on our institutional website (Potsdam Research Institute for Multilingualism, n.d.).

4. An anonymous reviewer suggested carrying out this complementary analysis for the HL speakers' data only, since including the data from the late bilinguals may have obscured potential individual-difference effects within the HL group. Running an additional model on the HL speakers' data yielded the same results as did our original analysis, however: We found significant effects of daily use of Turkish on the HL speakers' performance $(\beta=-0.016$, $\mathrm{SE}=0.006, \mathrm{z}=-2.751, p=0.005$ ), but no significant effects of age of acquisition on German or self-rated Turkish proficiency (both $p \mathrm{~s}>0.45$ ). 